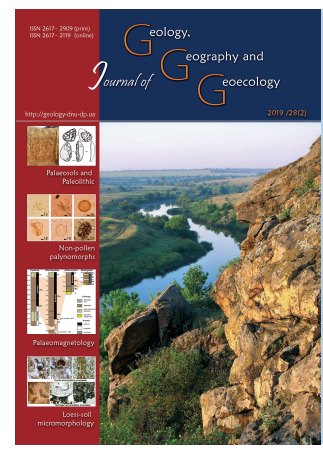

Journal of Geology.

ISSN 2617-2909 (print)

ISSN 2617-2119 (online)

Geography and

Geoecology

Journ.Geol.Geograph.

Geology,

28(2), 241-249.

Journal home page: geology-dnu-dp.ua

doi: $10.15421 / 111925$

Kseniia Bondar, Bogdan Ridush, Mariia Baryshnikova, Yana Popiuk

Journ. Geol. Geograph. Geoecology, 28(2), 241-249.

\title{
On palaeomagnetic dating of fluvial deposits in the section of Neporotove gravel quarry on the Middle Dniester
}

\author{
Kseniia Bondar ${ }^{1}$, Bogdan Ridush ${ }^{2}$, Mariia Baryshnikova $^{1}$, Yana Popiuk ${ }^{2}$ \\ ${ }^{1}$ Taras Shevchenko National University of Kyiv, Kyiv, Ukraine \\ ${ }^{2}$ Yuriy Fed'kovych Chernivtsi National University, Chernivtsi, Ukraine \\ e-mail:ks_bondar@ukr.net,b.ridush@chnu.edu.ua
}

Received: 12.04 .2019

Received in revised form: 03.05.2019

Accepted: 12.05.2019
Abstract. The paper presents the results of palaeomagnetic studies of Quaternary noncemented deposits from the section of Neporotove on the VIIIth terrace of the Dniester River valley with abnormal thickness (more than $20 \mathrm{~m}$ ) of the channel alluvium near the village of Neporotove, located on the right bank of the Dniester River. Alluvial facies of river terraces' deposits are valuable palaeogeographic archives but not quite complete. They are affected by denudation and often do not contain fossils. The possible way for their dating is provided by a palaeomagnetic method performed on suitable for sampling underlying and overlying beds. The alluvial sequence consists of four units. Unit I is composed of inclined gravel-pebble layers with the sand filler with a visible thickness of about $8 \mathrm{~m}$. Unit II has bedded over the denudated surface of Unit I; it consists of light-yellow laminated aleurit loam, 5-30 cm thick underlaid by $0.5-1.5$ bed of fine sand. We consider Unit II to be lacustrine deposits accumulated in quiet water. Unit III is represented with inclined or sub-horizontally layered gravel-pebble-boulder deposits with up to $10 \mathrm{~m}$ of visible thickness. It includes boulders and blocks of sedimentary rocks up to 1.0 in diameter, considered as drop-stones. In the roof of the gravel-pebble Unit III, there is the white carbonate layer, probably, the illuvial horizon of the palaeosol $\left(m r_{l}\right)$, which transited up into the brownish-red horizon A (Unit IV). Unit IV - dark-red sandy-gravel horizon, pedosediment, probably partly the reworked material washed into ice wages in the roof of Unit III. As a result of alternating field stepwise demagnetisation of natural remanence of sediments, we determined that loamy Unit II, which separates members of gravel stratum, and sandy Unit IV, which overlays packs of gravel alluvium, bear characteristic remanent magnetisation (RM) with normal geomagnetic polarity. Taking into consideration lithology and two-fold structure of terrace gravel alluvium as well as palaeomagnetic results, we assume the lacustrine deposits of Unit II was formed during Jaramillo palaeomagnetic subchron corresponding to the end of Shyrokyne Stage, and a pedosediment of Unit IV was formed during Martonosha Stage. The upper alluvial suite of a terrace (Unit III) was generally deposited during a cold stage, directly prior to the onset of lacustrine loam sedimentation, while the lower alluvial member (Unit I) dates from the preceding warm stage. Thus, we defined the geological age of the whole channel alluvium strata of the VIIIth Dniester terrace as Shyrokyne-Pryazovya Stage.

Keywords: Dniester River, Neporotove gravel quarry, river terrace, palaeomagnetic dating, channel alluvium, remanent magnetisation

\section{Про палеомагнітне датування флювіальних відкладів у розрізі гравійного кар'єру Непо- ротове на Середньому Дністрі}

\author{
Ксенія Бондар ${ }^{1}$, Богдан Рідуш², Марія Баришнікова ${ }^{1}$, Яна Поп’юк² \\ ${ }^{1}$ Київський національний університет імені Тараса Шевченка, Київ, Украӥна \\ 2 Чернівецьький національний університет імені Юрія Федьковича, Чернівиі, Украӥна \\ e-mail:ks_bondar@ukr.net,b.ridush@chnu.edu.ua
}

Анотація. У роботі представлені результати палеомагнітних досліджень четвертинних пухких відкладів 3 розрізу VIII-ї надзаплавної тераси долини Дністра 3 надпотужними (понад 20 м) шарами руслового алювію біля села Непоротове, що на правому березі Дністра. Алювіальні фації відкладів річкових терас є цінними палеогеографічними архівами, але часто не повними. Значна частина відкладів зникає внаслідок денудації, флювіальні шари переважно $є$ палеонтологічно німими. Їхнє датування можливе за допомогою палеомагнітного методу, коли він застосовується на придатних для відбору зразків підстеляючих та перекриваючих відкладах. Розріз алювіальних відкладів у Непоротовому складається з чотирьох верств. Вер- 
ства I являє собою косошарувату гравійно-галечникову товщу з піщаними прошарками та видимою потужністю близько 8 м. Верства II залягає на денудованій поверхні верстви I, вона складається з світло-жовтого горизонтально шаруватого суглинку товщиною 5-30 см, який підстелюється 0,5-1,5 м шаром дрібного шаруватого піску. Верства II складена озерними відкладами, накопиченими в спокійних водних умовах. Верства ІІІ представлена похилими або субгоризонтально-шаруватими гравійногалечно-валунними відкладами з видимою товщиною до 10 м. Вона містить валуни і брили осадових порід діаметром до 1.0 м, які ми вважаємо дроп-стоунами. У покрівлі галечника верстви III знаходиться білий карбонатний прошарок - ймовірно, ілювіальний горизонт мартоноського викопного грунту $\left(m r_{l}\right)$, який догори переходить у бурувато-червоний горизонт А (верства IV). Верства IV -темно-червоний піщано-гравійний горизонт, педоседимент. Складається з переробленого матеріалу, вмитого до морозобійних тріщин в покрівлі верстви III. У результаті магнітної чистки зразків пухких відкладів змінним полем встановлено, що і суглиниста верства II, яка розділяє пачки гравійної товщі, і піщана верства IV, яка перекривають пачки гравійного алювію, мають пряму характеристичну намагніченість. Враховуючи подвійну будову руслового алювію, а також палеомагнітні результати, було висунуто припущення про приналежність шару II озерних відкладів до субхрону прямої полярності Харамільо, який стратиграфічно відповідає верхньому широкинському підетапу, а педоседименту IV до мартоноського палеокліматичного етапу. Верхній терасовий алювій (верства III) накопичився під час холодної стадії, безпосередньо перед початком осідання озерного суглинку, тоді як нижній алювій (верства I) датується попереднім теплим етапом. Отже, геологічний вік всієї товщі руслового алювію VIII-ї тераси визначено як широкинсько-приазовський.

Ключові слова: річка Дністер, гравійний кар'єр Непоротове, річкова тераса, палеомагнітне датування, русловий алювій, залишкове намагнічення.

Introduction. Alluvial facies of river terraces' deposits are valuable palaeogeographic archives containing records about the history of the formation of these rivers' valleys and climate change during corresponding periods. The lithofacial composition, stratigraphy, structure of the alluvium reflects the interaction of many processes, such as short-term migrations of individual channels to long-term vertical tectonic movements (Matoshko et al., 2004; Mial, 2006). Meanwhile, like most other types of continental deposits, the alluvial archives are not quite complete, as they are affected by denudation. In particular, they often do not contain fossils, being palaeontologically mute. The palaeomagnetic method performed on suitable for sampling underlying and overlying beds provides a possible way for their dating.

We examined a terrace section near the village of Neporotove, where previously the abnormal thickness of the channel alluvium exceeding $20 \mathrm{~m}$ was described (Ridush, Popiuk, 2015). As described in the literature, the channel alluvium strata in the terrace sediments of the middle part of the Dniester valley usually does not exceed several meters, and only occasionally, together with the floodplain facies, reach up to 15-16 $\mathrm{m}$ (Veklych, 1982). Just in the lower reaches of the Dniester the so-called "Tiraspol gravel" is known the river channel alluvium facia of Kolkotovo terrace, which is up to $15 \mathrm{~m}$ thick (Nikiforova et al., 1971). So, we faced the question of elucidating the age and the genesis of these strata, and their position within existing schemes of floodplain terraces.

This study reports the examination of characteristic magnetic remanence values in two layers of fine non-cemented sediments separating and overlaying coarse channel alluvium strata to estimate their magnetostratigraphic position relative to Brunhes-Matuyama geomagnetic polarity reversal. It leads to the dating of the VIIIth Dniester terrace.

Materials and methods. Many researchers studied the terraces of the middle reaches of the Dniester valley. The history of these studies is described in detail by O. Tomeniuk (2010). Her publication contains a comparison of the numbers and heights of terraces by different authors. So, within the middle part of the Dniester River valley Yu. Polyansky (1929) and S. Rudnytsky determined six terraces, R. Vyrzhykivskyi (1933) and I. Hofstein (Hofstein, 1979) - seven terraces, I. Ivanova (1969) - eight terraces, A. Yatsyshyn and A. Bogutsky (2008) - seven terraces, P. Gozhik and L. Lindner (2007) - thirteen terraces, M. Veklych (1982) - sixteen terraces. In this paper, we use the scheme of terraces by M. Veklych (1982), which, moreover, is used in State Geological Surveys in Ukraine.

Neporotove section. Previously the section was described by B. Ridush and Y. Popiuk (2015). The gravel outcrop uncovered by a quarry located on the northern outskirts of the Neporotove village (Sokyryany district, Chernivtsi region, Ukraine) (Fig. 1). Coordinates of the outcrop areN 48 36'32.47", E 2717'11.22". Bedrocks represented with: Proterozoic shales with the inclusions of phosphorite nodules; Cretaceous deposits of varying lithological composition, among which is gaize with inclusions of flint nodules; Sarmatian detrital and tortoiseshell limestones.

Although the Quaternary gravel-pebble stratum is generally fairly homogeneous, it is nevertheless divided into two horizons by light-yellow, finegrained laminated aleuritic loam (Unit II, Fig. 2, II),

The alluvial sequence consists of four units. 


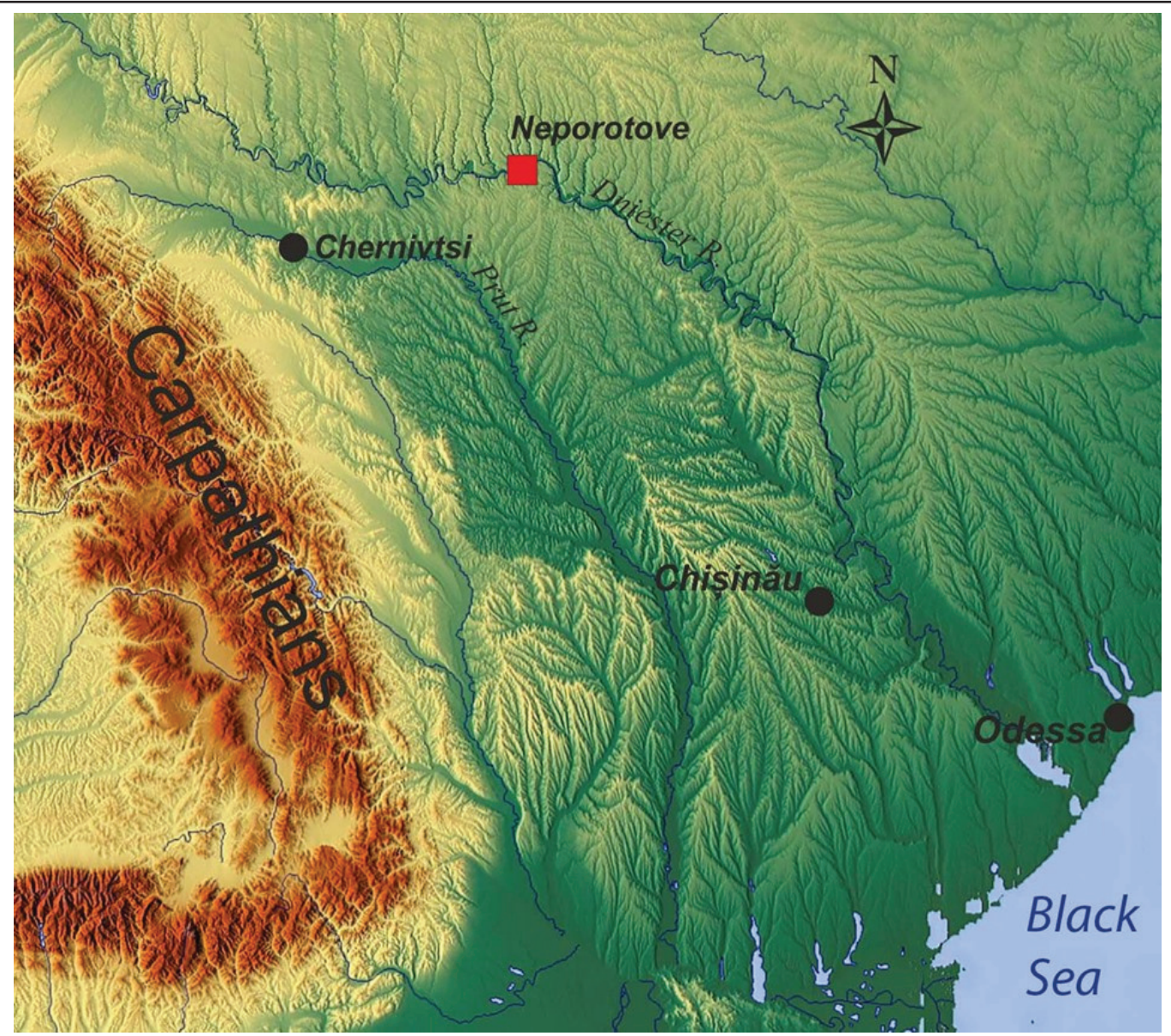

Fig. 1. Location of the Neporotove section of terrace deposits.

Unit I beds on the denudated surface of Ediacaran shale. It is composed of an inclined (the angle of approximately $30^{\circ}$ ) gravel-pebble layers with a sand filler (up to $20-30 \%$ of the volume), with a visible thickness of about $8 \mathrm{~m}$. Gravel and pebble stones are generally well-rounded and sub-rounded. The layers usually are $10-20 \mathrm{~cm}$ thick, with larger and smaller sand content, between which there are no clear boundaries, alternate down the section.

Unit II has bedded over the denudated surface of Unit I. It consists of light-yellow laminated aleurit loam, $5-30 \mathrm{~cm}$ thick, which is here and there underlaid by lenses (up to $0.5-1.5 \mathrm{~m}$ thick) of finegrained yellow and grey sand with gravel and pebble inclusions. We assume the lacustrine genesis of this stratum. It is evident that the loamy layer is quite dense and water-resistant, since directly over it in the covering gravel Unit III some suffosion channels with a diameter of 0.4-0.7 $\mathrm{m}$ have been traced.

Unit III - inclined (angle about $20^{\circ}$ ) or subhorizontally layered gravel-pebble-boulder deposits, with or without sand filler (up to $10 \%$ ), with up to 10 $\mathrm{m}$ of visible thickness. It lays with disconformity on the surface of Unit II, and, where Unit II is absent, on the surface of Unit I. There are overlapping layers of different granulometric composition: coarse pebbles, fine pebbles, gravel. Numerous inclusions (up to 10\%) of weakly rolled and non-rolled boulders of Sarmatian and Cretaceous limestones and sandstones, sometimes Devonian sandstones or quartz, with a diameter of 0.8 $1.0 \mathrm{~m}$ or more. There are pellets of Proterozoic dark grey, dark green, light green argillites in size from large pebbles to small boulders up to $0.5 \mathrm{~m}$ in diameter included in the strata. Among the pebble material, the weakly-rolled flint pebbles with traces of cryogenic weathering predominate (no less than 50\%). Lithology of gravel and pebble material is also represented by Devonian red sandstones, Sarmatian limestones, light Cretaceous limestones and sandstones. Presence of argillite pellets indicates that the flood (or floods) was extreme and the water jet tore out the fragments of argillite rocks, rather than picking up the products of weathering of argillite, which would take place under a usual flood. The large boulders we consider as dropstones, transported by river-ice. In the roof of Unit III, the ice wedges up to $1 \mathrm{~m}$ deep are often. In the roof of the gravel-pebble Unit III, there is the white carbonate layer, probably, the illuvial horizon of the palaeosol $\left(m r_{l}\right)$, which transited up into the brownishred horizon A (Unit IV). 


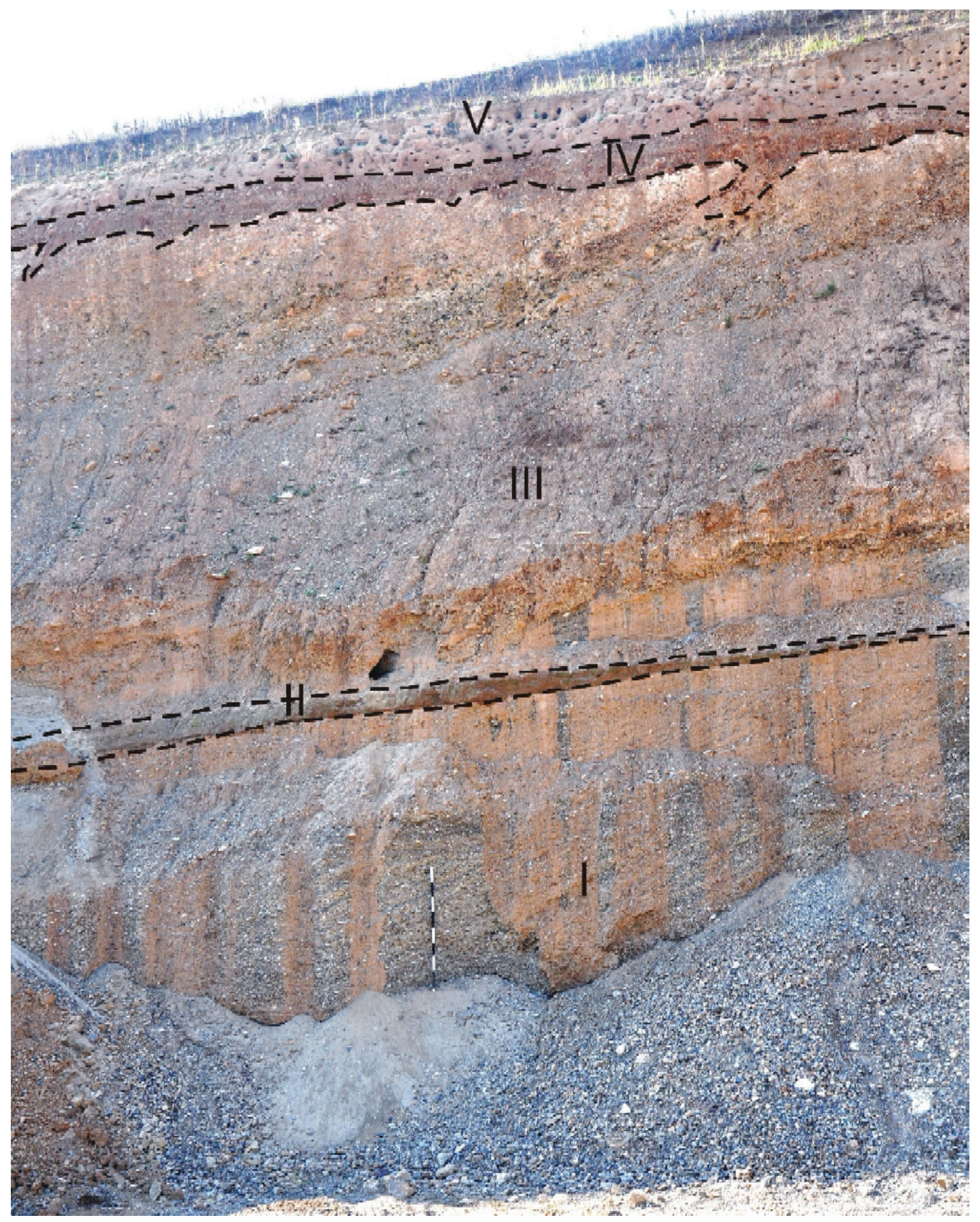

Fig. 2. Gravel-pebble alluvium at the Neporotove outcrop. I - Unit I, the lower gravel-pebble bed of low-angle crossbedding; II - Unit II, the loam layer, light yellow, laminated; III - Unit III, the upper gravel-pebble bed of low-angle cross-bedding, with domination of macro-fragmental material and drop-stones at the roof of the bed; IV - dark-red sandy-gravel, V - Unit V subaerial loess deposits of unknown age (Ridush, Popiuk, 2015). The scale stick on the photo is $2 \mathrm{~m}$ long.

Unit IV - dark-red sandy-gravel horizon, probably partly the reworked material of Unit III, coloured by the illuvium of red palaeosol, here and there washed into ice wages in the roof of Unit III. Thickness is around $0.4-0.6 \mathrm{~m}$.

From 1.0 to $4.0 \mathrm{~m}$ of loess and loess loams of undefined age are deposited above (Unit V).

Sampling and measurements. Since the gravelpebble deposits of Units 1 and 3 are not suitable for paleomagnetic examination, we focused on sampling Units 2 and 4 in order to achieve the objectives of the study. From the horizontally-layered loamy Unit II, we cut two samples from two stratigraphic levels, from which in the laboratory we drilled six $2.5 \mathrm{~cm}$ specimens for palaeomagnetic measurements using the standard procedure (Butler, 1992).

From the reddish sandy Unit IV at the top of the upper gravel-pebble layer we manually cut nine 

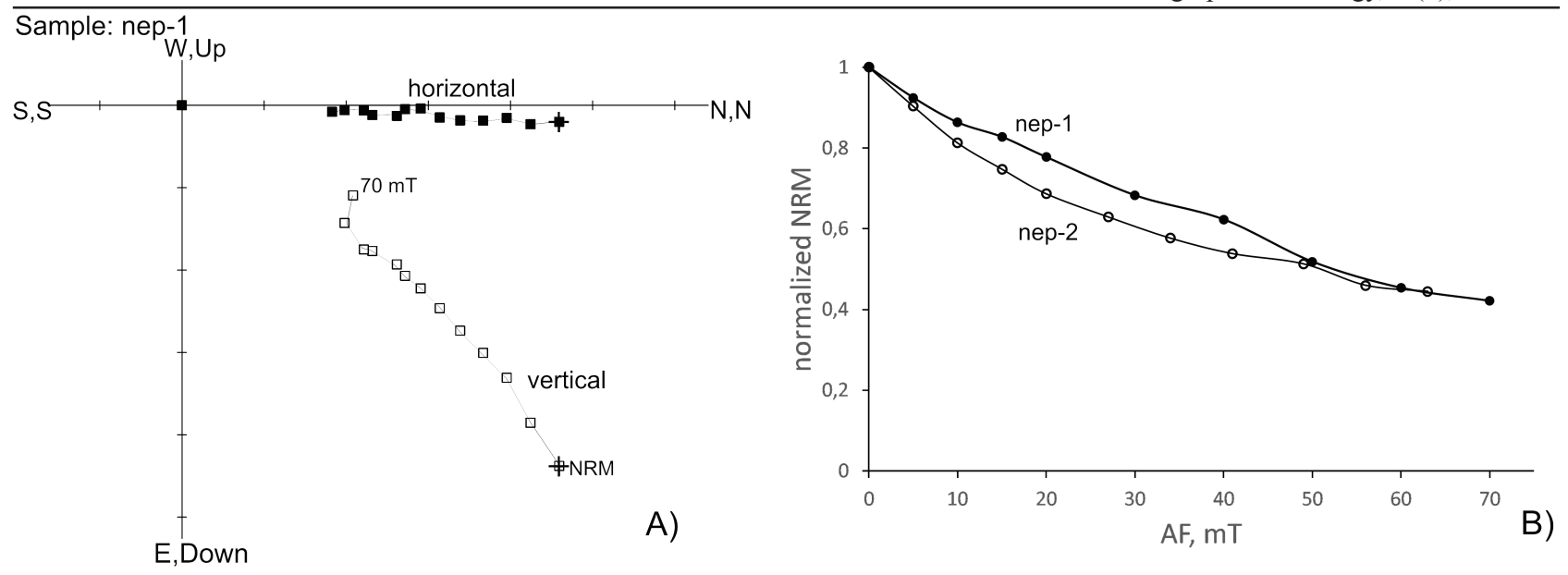

Fig. 3. Examples of AF-demagnetization of specimens from Unit II: (A) characteristic Zijderveld plot and NRM decay curves during AF demagnetization (B).

$2.5 \mathrm{~cm}$ cylinder specimens. A magnetic compass was used to provide an unequivocal in situ geographic orientation of each manually cut sample.

The measurements were performed in the Ivar Giæver Geomagnetic Laboratory at the University of Oslo (Oslo, Norway) and the magnetic laboratory of ESI «Institute of Geology» of the Taras Shevchenko National University of Kyiv (Kyiv, Ukraine).

The magnetic susceptibility (k) of all samples was measured on Geofyzika KLY-2 Kappabridge.

The remanent magnetisation of specimens was measured using a three-axis WSGI Model 755 SRM (WSGI, USA) cryogenic rock magnetometer. The stable characteristic remanent magnetisation (ChRM) of samples was isolated by stepwise alternating field demagnetisation in a $2 \mathrm{G}$ demagnetizer (with steps of 2.5-10 mT until $70 \mathrm{mT}$ for specimens from Unit II and $100 \mathrm{mT}$ for specimens from Unit IV).

The Keonigsberger ratio $(\mathrm{Q}=\mathrm{NRM} / \mathrm{Ji}, \mathrm{Ji}-$ induced magnetization) characterising relative magnetic hardness of the material (Evans and Heller, 2003) was calculated.

Results. Since the fluvial sediments represent the re-deposited in shallow water loamy and sandy material, their characteristic remanent magnetisation is rather depositional (DRM) with possible postdepositional (PDRM) contribution. DRM is formed due to the orientation of magnetic particles along the magnetic field during settling in the water and staying in the upper bottom layer until the sediment is compacted. In this case, the vectorial components of the magnetisation - inclination (I) and declination (D) may be biased due to the direction of the waterflow and because of the settling of the elongated magnetic grains when falling on the horizontal bottom. The latter leads to a shallowed I compared with the geomagnetic field inclination of the time and place of sediment's formation (Tauxe, 2018). The magnetisation of sediments could be formed after the formation of a layer (PDRM). Under certain conditions "rejuvenation" of magnetisation relative to the age of the formation of the loose stratum itself is evidenced by the absence of inclination shallowing (Kodama, 2012).

NRM of loam from Unit II makes 6.2...6.5*10-3 $\mathrm{A} / \mathrm{m}$, $\mathrm{k}$ makes $245 \ldots 280^{*} 10^{-6} \mathrm{SI}$ un. These values are typical for loess deposits from loess-palaeosol sequences of Ukraine. The NRM is relatively "hard"; the median destructive field(MDF) is 45-55 $\mathrm{mT}$, theKeonigsberger ratio $Q$ is $0.45 \ldots 0.50$. The demagnetization path on the Zijederveld plots exibit almost straight line and is directed toward the origin. The magnetic declination $\mathrm{D}$ of the characteristic component (isolated under the AF-demagnetizing procedure in the range of 10-63 $\mathrm{mT}$ ) is $-12 \ldots 3^{\circ}$; the inclination is shallowed relatively to the inclination of the recent geomagnetic field and makes $38 \ldots 51^{\circ}$. Examples of Zijderveld plots and NRM demagnetisation curves are shown in Fig. 3.

Thus, we can conclude that the entire stratum bear ChRM with normal geomagnetic polarity, ChRM is probably depositional.

NRM and $\mathrm{k}$ of samples from Unit IV demonstrate low values. NRM makes $1,2 \ldots 4,3 * 10^{-3} \mathrm{~A} / \mathrm{m}, \mathrm{k}$ makes $142 \ldots 242 * 10^{-6}$ SI un. MDF makes $11-14 \mathrm{mT}$, the Q is $0.16 \ldots 0.59$ indicating presence of low-coercive magnetic mineral. As recognized from NRM decay curves, the remanence of samples probably consists of two components, relatively soft one is presumably viscous, it makes up to $65 \%$ of remanence. The demagnetization path on the Zijedrvild plots exibit almost straight line and is directed toward the origin, as both components of the NRM are directed equally. 

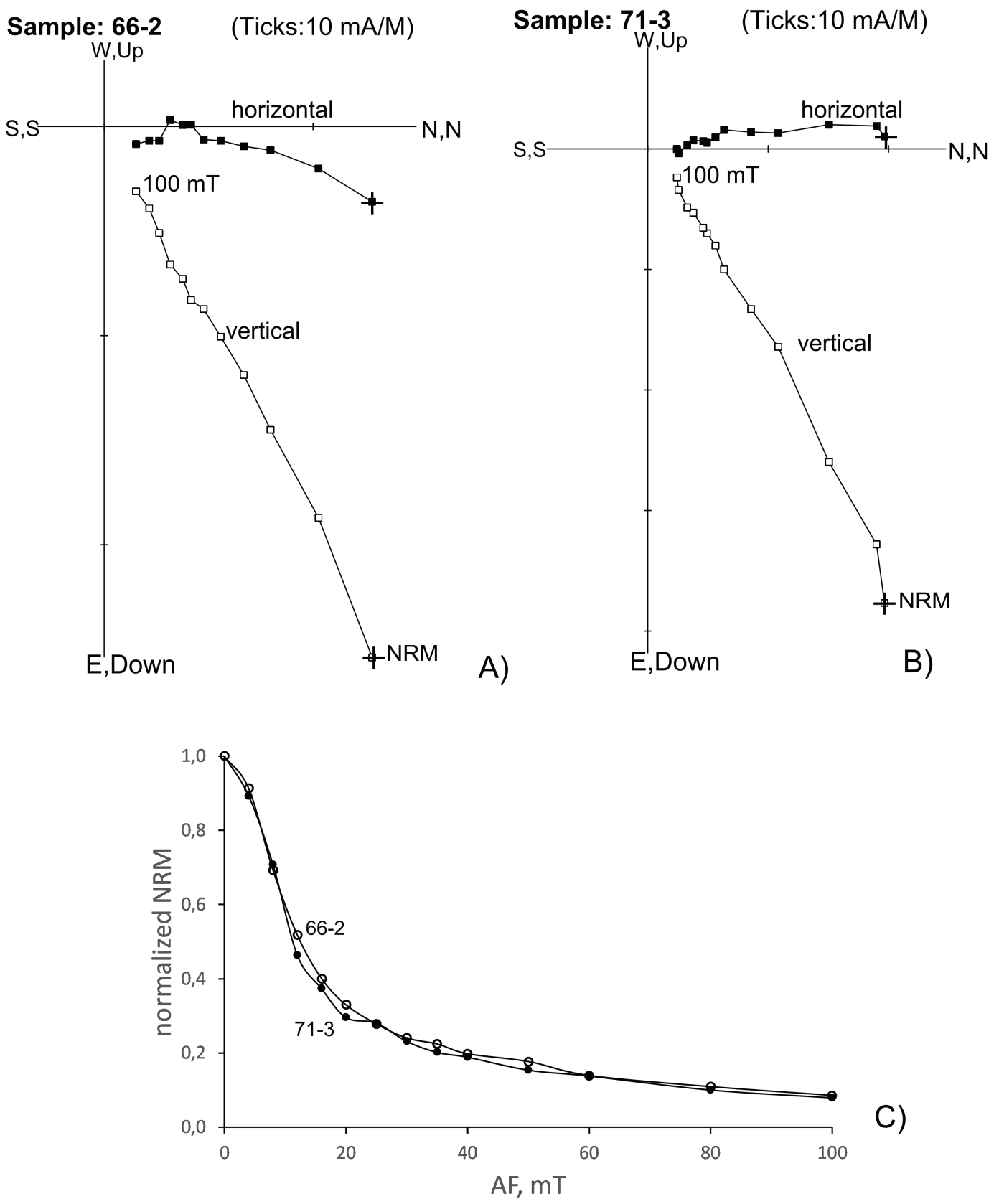

Fig. 4. Examples of AF-demagnetization of specimens from Unit IV: characteristic Zijderveld plots (A, B) and NRM decay curves during AF demagnetization (C).

The magnetic declination of the harder characteristic component (isolated under AF-demagnetizing procedure in the range of $20-100 \mathrm{mT}$ ) is $-2 \ldots 6^{\circ}$, the inclination corresponds to the inclination of the recent geomagnetic field and makes $65 \ldots 71^{\circ}$. Examples of Zijderveld plots and NRM demagnetisation curves are shown in Fig. 4. We can conclude that the sediment acquired the magnetisation in the period of normal geomagnetic polarity, characteristic RM is probably post-depositional.

Discussion. When considering the possible age of the alluvium, it is crucial to determine which lithological horizon may bear the Matuyama-Bruhnes boundary (MBB) - the main Quaternary benchmark.
It is important to consider modern ideas about the position of $\mathrm{MBB}$, as this will significantly contribute to the correct interpretation of the palaeomagnetic results on the background of climate-stratigraphic evidence from the fluvial facies.

According to the magnetostratigraphic scale of Pleistocene of Ukraine (Tretyak and Vigilyanskaya, 1994), composed on the base of the regional stratigraphic scheme of the loess-palaeosol sequence of the Central Ukraine (Veklych, 1984) the MBB lays in the bottom of Shyrokyne unit. Early palaeomagnetic studies in the area of Lower Dniester put MBB into the loess mantle above the alluvium of the VIIIth terrace (Pevzner and Chepalyga, 1970; Pospelova 


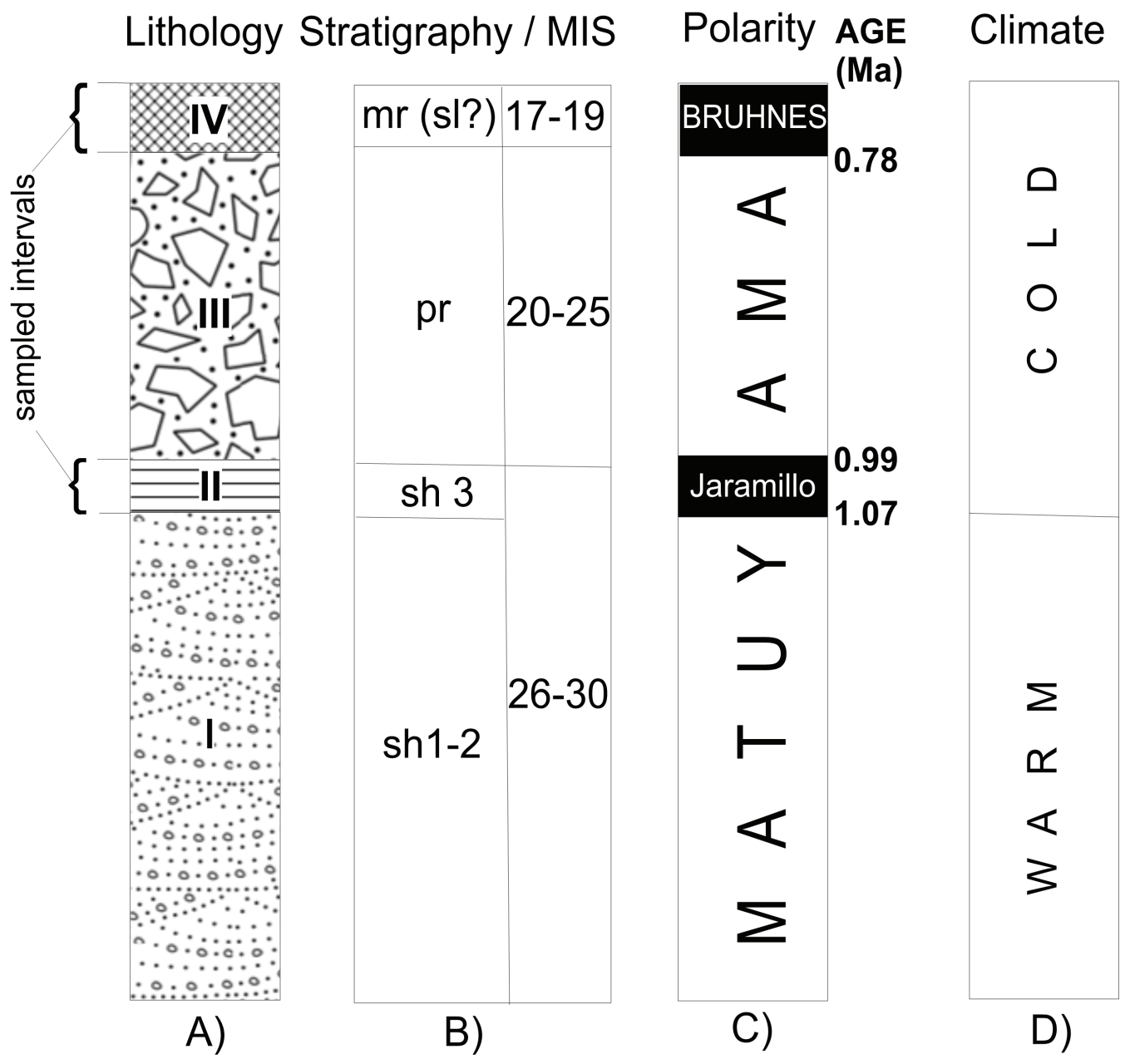

Fig. 5. Lithology (A): I - inclined gravel-pebble layers with a sand filler, thickness of about $8 \mathrm{~m}$, II - light-yellow laminated aleurit loam, 5-30 cm thick, III - gravel-pebble-boulder deposits, up to $10 \mathrm{~m}$ of visible thickness, IV - darkred sandy-gravel horizon, thickness around 0.4-0.6; stratigraphy with oxygen isotope stages (MIS) after (Gerasimenko, 2010) (B); magnetic polarity after (Cande, 1995) (C); and climate (D) of Dniester channel alluvium in Neporotove section.

and Gnibidenko, 1972; Trubikhin and Chepalyga, 1986). In the summarising publication (Lindner et al., 2006), which include data on the Upper, Middle, and Lower Dniester reaches, the MBB was lifted to the boundary of the Pryazovya and Martonosha units of Stratigraphic scheme of the Pleistocene of Ukraine (Veklych, 1984).

According to recent studies performed on precise magnetic equipment, the MBB was not distinguished in the section of Prymors'ke (Nawrocki et al., 1999), which is underlain with the soils of the Martonosha unit. The MBB was defined in the upper part of the Martonosha unit in the Dolynske section (Bakhmutov et al., 2005), in the lower part of the Shyrokyne palaeosol in the section of Viazivok (Glavatsky et al., 2016, Bakhmutov, Glavatsky, 2016). However, in the Viazivok section, the Martonosha unit was missed during sampling, and the authors themselves suspect that the palaeomagnetic record could be aged due to lock-in depth effect. In the section of Roksolany, the MBB was defined at the junction of buried soils of the Lubny and Martonosha units (Bakhmutov, and Glavatsky, 2014; Bakhmutov et al., 2017), relying on the temperature demagnetisation of RM. But authors also provide the data of AF-demagnetization of RM, according to which the MBB should be determined lower, in the Pryazovya unit. The AF-demagnetization method seems to be preferable for soils and loess since during the high-temperature heating experiment the formation of new minerals occur (Evans, 2003).

Thus, the most reasonable for today is the position of the MBB on the contact between the Pryazovya loess and the Martonosha palaeosol, as presented in the paper (Lindner et al., 2006).

Veklych and Dubniak (1975) considered that on the most of river terraces alluvium has a twofold structure. The uppermost alluvial layer passes upwards into loess with a subaerial palaeosol 
developed in its upper part and further burial by a sequence of younger loesses and soils. The upper alluvial suite of a terrace was generally formed during a cold stage, directly prior to the onset of aeolian loess sedimentation, while the lower alluvial member dates from the preceding warm stage. Thus, the alluvium of a terrace corresponds to a certain loess-soil couplet on interfluve areas, i.e. to a particular climatic cycle. Matoshko with co-authors (Matoshko et al., 2004) consider this approach problematic because the evidence from the fluvial facies themselves is neglected in favour of simplistic climate-stratigraphy. Nevertheless, we still use this approach.

The palaeomagnetic record of sediments may provide chronostratigraphic information as sediments may acquire magnetic remanence upon deposition and shortly after deposition.

According to this, the normal polarity sandy Unit IV should be attributed to the Martonosha unit $(\mathrm{mr})$. Without contradicting the geological data, it can be assumed that the normal polarity of Unit II may indicate its formation during the Jaramillo subchron inside the Matuyama Chron of reversed polarity, i.e. in the range of 0.99-1.07 million yrs. (Cande and Kent, 1995), which corresponds to the end of the Shyrokyne stage (sh3) (Lindner et al., 2006).

Such an interpretation makes it possible to limit the upper dating of the lower alluvium Unit I to 1.07 million years. So, the Unit I itself can be attributed to the Shyrokyne 1-2 subunits (MIS 24). Going further in our assumptions, let us point out that the erosion of loamy sediments of Unit II and the accumulation of the upper gravel pack of Unit III occurred in Pryazovya Stage (Fig.5).

Conclusion. The layers of non-cemented deposits that separate and overlay alluvium packs were formed during periods of normal geomagnetic polarity. We assume the Unit II of lacustrine deposits we attributed to Shyrokyne-3 unit, the normal polarity zone found here is correlated to the Jaramillo subchron. Unit IV belongs to the Martonosha unit; however, this pedosediment was formed during one of cold Martonosha substages by inwashing the material to frost-cracks in gravel Unit III.

We defined the geological age of the channel alluvium of the VIIIth terrace of the Dniester River as Shyrokyne-Pryazovya.

Acknowledgements. We are grateful to the Ivar Giæver Geomagnetic Laboratory (IGGL) for the use of their facilities. The IGGL is funded by the Research Council of Norway (project \#226214) and the Centre for Earth Evolution and Dynamics, University of Oslo.

\section{References}

Bakhmutov V. G., Mokryak I. N., Skarboviychuk T. V., Yakukhno V. N., 2005. Rezultaty palaeomagnitnykh issledovanij razreza dunajskikh terras $\mathrm{i}$ problemy magnitostratigrafii pleistocena Zapadnogo Prichernomor'ja [Results of palaeomagnetic study of Danube terrace section and problems of Pleistocene magnetostratigraphy of Western Black Sea region]. Geofizicheskiy zhurnal 27(6), 980-991 (in Russian).

Bakhmutov, V., Glavatskyi, D., 2014. New data for the Matuyama-Brunhes boundary in the Roksolany section, Geologichnyi Zhurnal, vol. 347, no. 2, pp. 73-84.

Bakhmutov, V., Glavatskyi, D., 2016. Pleistocene Magnetostratigraphy Problems of the loess-soil deposits of the south of Ukraine, Geofiz. Zh., vol. 38, no. 4, pp. 59-74.

Bakhmutov, V.G., Kazanskii, A.Y., Matasova, G.G., Glavatskii D. V., 2017. Rock magnetism and magnetostratigraphy of the loess-sol series of Ukraine (Roksolany, Boyanychi, and Korshev sections) Izv., Phys. Solid Earth 53: 864. https:// doi.org/10.1134/S1069351317050020

Butler, R.F., 1992. Palaeomagnetism: Magnetic Domains to Geologic Terrains. Blackwell Scientific, Boston, Oxford.

Cande, S.C.and Kent, D.V., 1995, 'Revised calibration of the geomagnetic polarity timescale for the late Cretaceous and Cenozoic', J.Geophys.Res. vol. 100, no. B4, 6093-6095.

Evans, M.E., Heller, F., 2003. Environmental Magnetism. Principles and Applications of Enviromagnetics. In: International Geophysics Series. Elsevier Science, USA.

Gerasimenko N.P., 2010. Korelyatsija korotkoperiodychnyh etapiv pleistotsenu za paleolandshaftnymy danymy [Correlation of short-period stages of Pleistocene by palaeolandscape data]. In: Prostorovochasova koreliatsija paleogeografichnyh umov chetvertynnogo periodu na terytoriji Ukrainy [Spatial-temporal correlation of Quaternary palaeogeographic conditions on the territory of Ukraine] / Ed. Zh.M. Matvijishyna. Kyiv, Naukova Dumka, 104-129 (in Ukrainian).

Glavatskii D.V., Kuzina D.M., Gerasimenko N.P., Bakhmutov V.G., 2016. Petromagnetizm I palaeomagnetizm chetvertichnykh lyossovopochvennykh otlozhenij razreza Viazovok (Pridneprovskaya nizmennost) [Petromagnetism and palaeomagnetism of Quaternary loesssoil sediments of Vyazivok section (Dnieper Lowland)]. Geofizicheskiy Zhurnal, [S.1.], v. 38, n. 6, p. 186-193 (in Russian).

Gozik P., Lindner L., 2007. Tarasy srodkowego i dolnego Dniestru oraz ich znaczenie w badaniach nad plejstocenem Europy. Systemy dolinne i ich 
funkcjonowanie. Prace Instytutu Geografii. № 16. S. 27-42.

Hofstein I.D., 1979. Neotektonika zapadnoj Volyno-Podolii [Neotectonics of the Western Volyno-Podolia]. Naukova Dumka, Kiev, 155 p. (in Russian).

Kodama, K. P., 2012. Palaeomagnetism of Sedimentary Rocks: Process and Interpretation. Oxford: WileyBlackwell.

Lindner, L., Bogutsky, A., Gozhik, P., Marks, L., Lanczont, M., Wojtanowicz, J., 2006. Correlation of Pleistocene deposits in the area between the Baltic and Black Sea, Central Europe, Geol. Quart., no. 1, pp. 195-210.

Matoshko A.V., Gozhik P.F., Danukalova G., 2004. Key Late Cenozoic fluvial archives of eastern Europe: the Dnister, Dniper, Don and Volga. Proceedings of the Geologists' Association, 115, 141-173.

Mial, A.D., 2006. The geology of Fluvial Deposits. Sedimentary Facies, Basin Analysis, and Petroleum Geology. 4th printing. Berlin Heidelberg - New York: Springer, 582 p.

Nawrocki, J., Bakhmutov, V., Bogucki, A., and Dolecki, L., 1999. The palaeo and petromagnetic record in the Polish and Ukrainian loess-palaeosol sequences, Phys. Chem. Earth A, vol. 24, no. 9, pp. 773-777.

Nikiforova, K.V., Ivanova, I.K., Konstantinova, N.A., 1971. Tiraspol' kak opornyj razrez pleistocena Yevropy [Tiraspol as a type locality for the Pleistocene of Europe]. In: Nikiforova K.V. et al. (eds.) Pleistocene of Tiraspol. Shtiintsa, Kishinev, 187 p. (in Russian).

Pevzner, M.A., Chepalyga, A.L., 1970. Palaeomagnitnuye issledovaniya pliotsen-chetvertichnykh terras Dnestra [Palaeomagnetic studies of the Pliocene and Pleistocene Dniester terraces]. Doklady Akad. Nauk SSSR, 194 (1), 1142-1144 (in Russian).

Polianskyi, Y.I., 1929. Podil'ski etiudy: terasy, lesy i morfologiya Galytskogo Podillya [Podolian Essays: terraces, loesses and morphology of Halytske Podillya]. Zbirnyk matematychnopryrodnycho-likarskoyi sektsii Naukovogo Tovarystva Shevchenka, 16, $311 \mathrm{p}$.

Pospelova, G.A., Gnibidenko, Z.N., 1972. Palaeomagnetic investigations of the Quaternary terraces of the Southern Dniester area. Geofizicheski Sbornic, 47, Siberian Department of the Russian Academy of Science, Novosibirsk (in Russian).

Ridush B., Popiuk Y., 2015. Anomalni potuzhnosti ruslovogo aliuviyu $\mathrm{V}$ terasovyh vidkladah Seredniogo Podnistrov ja [Abnormal thickness of channel alluvium on the Middle Dniester] Scientific Herald of Chernivtsi Univ.: Geography.
Chernivtsi National University, Chernivtsi, 762763, 49-57 (in Ukrainian).

Tauxe, L, Banerjee, S.K., Butler, R.F. and van der Voo R., 2018. Essentials of Palaeomagnetism, 5th Web Edition.

Tomeniuk, O., 2010. Yurij Polians'kyj - doslidnyk teras Dnistra [Yuriy Polianskyi as a researcher of terraces of Dniester River]. Visnyk Lvivskogo Universytetu, Ser. Geogr., N 38: 340-356 (in Ukrainian).

Tretyak A.N., Vigilyanskaya L.I., 1994. Magnitostratigraficheskaya shkala plejstocena Ukrainy [Pleistocene magnetostratigraphic scale of Ukraine]. Geofizicheskiy zhurnal, vol.16, № 2, p. 3-14 (in Russian).

Trubikhin, V.M., Chepalyga, A.L., 1986. Palaeomagnitnaya stratigraphiya Pliotsena I Pleistotsena Moldavii [Palaeomagnetic stratigraphy of the Pliocene and Pleistocene in Moldavia]. In: Negodaev-Nikonov, K.N. (Ed.), Faunal Assemblages, Biostratigraphy of the Pliocene and Pleistocene of Moldavia. Stiintsa, Kishinev, pp. 30-31 (in Russian).

Veklich, M.F., Dubniak, V.O., 1975. Palaeogeografichni etapy utvorennia teras Seredniogo Dnipra [Palaegeographical stages of the Middle Dnieper terraces fonnation]. In (Marinich, O.M.; ed.) Problemy geographichnoi nauky v UkrSSR [Problems of Geography in rhe Ukrainian SSR . Naukova Dumka, Kiev, Ukraine, $74-86$ (in Ukrainian).

Veklich, M.F., Sirenko, N.A., Matviishina, Zh.N., 1984. Palaeogeograficheskie etapy i detal'noe stratigraficheskoe raschlenenie pleistotsena Ukrainy (Palaeogeographic Stages and Detailed Stratigraphic Division of the Pleistocene of Ukraine), Kiev, Nauk. Dumka, 32 p. (in Russian).

Veklych, M.F., 1982. Palaeoetapnost i stratotipy pogrebyonnyh formatsyj verkhnego kaynozoya [Palaeostages and stratotypes of soil formations of the Upper Cenozoic]. Naukova Dumka, Kiev, 201 p. (in Russian).

Vyrzhykivskyi, R., 1933. Geological map of Ukraine. Sheets XXVI-6 i XXVII-6 (Naddnistrianshchyna: Mogyliv - Yampil'). Geologo-rozviduvalnyi Trest, Kyiv, 226 p. (in Ukrainian).

Yatsyshyn, A., Bogutskyi, A., 2008. Etapy pleistocenovogo morfogenezu dolyny Dnistra $u$ halytskomu Prydnistrov`ji na osnovi analizu lesovogruntovyh pokryviv teras [Stages of Pleistocene morphogenesis of the Dniester valley in Galychyna Trans-Dniester on the basis of analysis of loess-soil-cover of terraces]. Visnyk Instytutu Arheologii, 3 : 3-7 (in Ukranian). 